УДК 620.92

\title{
СТВОРЕННЯ КОНКУРЕНТНОГО РИНКУ БІОПАЛИВ В УКРАЇНІ. ЧАСТИНА 2
}

\author{
Гелетуха Г.Г., канд. техн. наук, Желєзна Т.А., канд. техн. наук, Баштовий А.І., канд. техн. наук
}

Інститут технічної теплофізики НАН України, вул. Желябова, 2а, Київ, 03680, Украӥна

Представлено опис, аналіз роботи та основні результати функціонування литовської біопаливної біржі. Показано iï позитивний вплив на розвиток ринку паливної біомаси у Литві. Запропоновано можливі шляхи та моделі створення конкурентного ринку біопалив в Україні.
Представлены описание, анализ работы и основные результаты функционирования литовской биотопливной биржи. Показано ее положительное влияние на развитие рынка топливной биомассы в Литве. Предложены возможные пути и модели создания конкурентного рынка биотоплив в Украине.
Description, analysis and main results of operation of Lithuanian biomass exchange are presented. Positive impact of the biomass exchange on the development of the biofuel market in Lithuania is shown. Possible ways and models for the creation of the competitive biofuel market in Ukraine are suggested.

Бібл. 6, табл. 3, рис. 1 .

Ключові слова: біомаса, біопаливо, деревне біопаливо, ринок біопалива, біопаливна біржа.

БМ - біомаса;

ВДЕ - відновлювані джерела енергії;

\section{Литовська біопаливна бірэса та ї̈ вплив на місцевий ринок біомаси}

Литовська біопаливна біржа Baltpool є першою та єдиною біопаливною біржою в Європі. Розгляд успішного прикладу іiі роботи представляє значний інтерес для України з точки зору вивчення та запровадження найкращих підходів до організації функціонування біржі.

Ринок біомаси як палива в Литві розвивається протягом більше 15 років. За даними 2015 р., споживання біомаси для енергетичних потреб становило 435 тис. т н.е. В системі централізованого теплопостачання частка біомаси виросла з 1 \% у 1997 р. до $61 \%$ у 2015 р. Головним чином, це деревна біомаса, але також використовуються солома, біогаз та тверді побутові відходи. Незважаючи на стійкий ріст обсягів споживання біомаси у централізованому теплопостачанні, вартість теплової енергії також зростала до 2012 року включно (до близько 80 євро/МВт год без ПДВ). Після 2013 року спостерігається стала тенденція зниження вартості теплової енергії (2016 р. - в середньому 55 євро/МВт·год, що еквівалентно близько 1824 грн./Гкал) [1,2].

До створення біопаливної біржі ринок паливної біомаси в Литві характеризувався значною різницею у цінах на біомасу (до 25 \%), яку купляли регульовані ТЕЦ, розташовані у сусідніх районах. Крім того, на ринку була представлена обмежена кількість постачальників біомаси, особливо крупних. У 2012 р. почала свою роботу литовська біопаливна біржа Baltpool. Перша модель біржі була розрахована на невеликі торгівельні угоди тривалістю у тиждень, які укладалися додатково до існуючих двосторонніх контрактів. У 2013 р. було запроваджено нову торгівельну модель, розраховану на забезпечення довгострокових поставок біомаси. На сьогодні річний товарообіг біржі складає більше 56 млн.
ТЕЦ - теплоелектроцентраль; н.е. - нафтовий еквівалент.

євро. Щомісячна кількість операцій становить $300 \ldots 350$ одиниць. На біопаливній біржі зареєстровано більше 260 учасників.

Ліцензування діяльності Baltpool виконується Національною комісією 3 управління енергетикою та цінами. До правління енергобіржі входить представник Міністерства Енергетики Литовської Республіки. Акціонерами є дві крупні державні енергетичні компанії UAB "EPSO-G" (67\%) i AB "Klaipedos Nafta" (33\%), тому одна з основних задач роботи біржі відображає загальнодержавну ціль - посилення конкуренції на ринку енергоресурсів $[1,3]$.

Після створення біопаливної біржі ринок біомаси в Литві став набагато прозорішим, а його функціонуванняефективнішим. Завдяки роботі біржі, зниження вартості біомаси у 2015 р. порівняно з 2012 р. склало (в залежності від конкретного району) до $40 \%$, а різниця у вартості біомаси між сусідніми районами майже зникла. Протягом 2014-2016 рр. середня вартість біомаси на біржі була на 5...15\% нижче ціни, по якій ТЕЦ купляли біомасу напряму у постачальників, тобто поза біржою. Також вирішилася проблема обмеженої кількості постачальників біомаси через можливість залучення нових компаній на ринок. При цьому 96 \% постачальників біомаси - це литовські компанії, і тільки 4 \% припадає на зарубіжні.

Національна Програма розвитку сектору теплопостачання Литви на період 2015-2021 рр. запровадила зобов'язання для регульованих енергокомпаній купляти тверду біомасу на енергетичній біржі Baltpool: 2014 p. $10 \%, 2015$ p. - $50 \%, 2016$ р. - $100 \%$ загального обсягу споживання. По факту, частка біомаси, придбаної на біржі, збільшилася з 1 \% у 2013 р. до $64 \%$ ( 240 тис. т н.е.) у 2015 p. та $86 \%$ ( 230 тис. т н.е.) у 2016 р. (рис. 1$)$.

Для того, щоб стати учасником біржі, кожна компанія має відповідати ряду вимог, викладених у 
Правилах Енергобіржі та ряді інших документів [4]. Тривалість укладених контрактів $€$ різною в залежності від конкретних потреб і може складати тиждень, місяць, квартал, півроку або інший термін (на вимогу). Наразі біржа працює 3 наступними стандартизованими біопаливами: чотири види деревної тріски, три види деревних гранул, а також фрезерний торф (табл. 1-3) [5]. За потреби можуть бути додані нові види біопалива.

Торгівельні аукціони на біопаливній біржі проводяться щотижнево у другий робочий день тижня. Продавці (постачальники біомаси) та покупці (зазвичай, виробники теплової енергії) спілкуються анонімно.
Заявки на продаж/покупку біопалива подаються через Електронну систему торгів [6]. Участь у торгах коштує 0,7 євро/т н.е. Протягом аукціону відбувається пошук відповідності між наявними заявками на продаж та купівлю, і у випадку виконання ряду умов відбувається укладання угоди. Приклади умов відповідності: максимальна відстань транспортування, заявлена продавцем, не перевищує реальної відстані до конкретного покупця; метод визначення обсягу поставленої біомаси, яким користується покупець (вимірювання об'єму або ваги), $\epsilon$ прийнятним для продавця.

\section{Обсяг БМ, тис. т н.е.}

\section{Частка БМ, придбаної на біржі, \%}

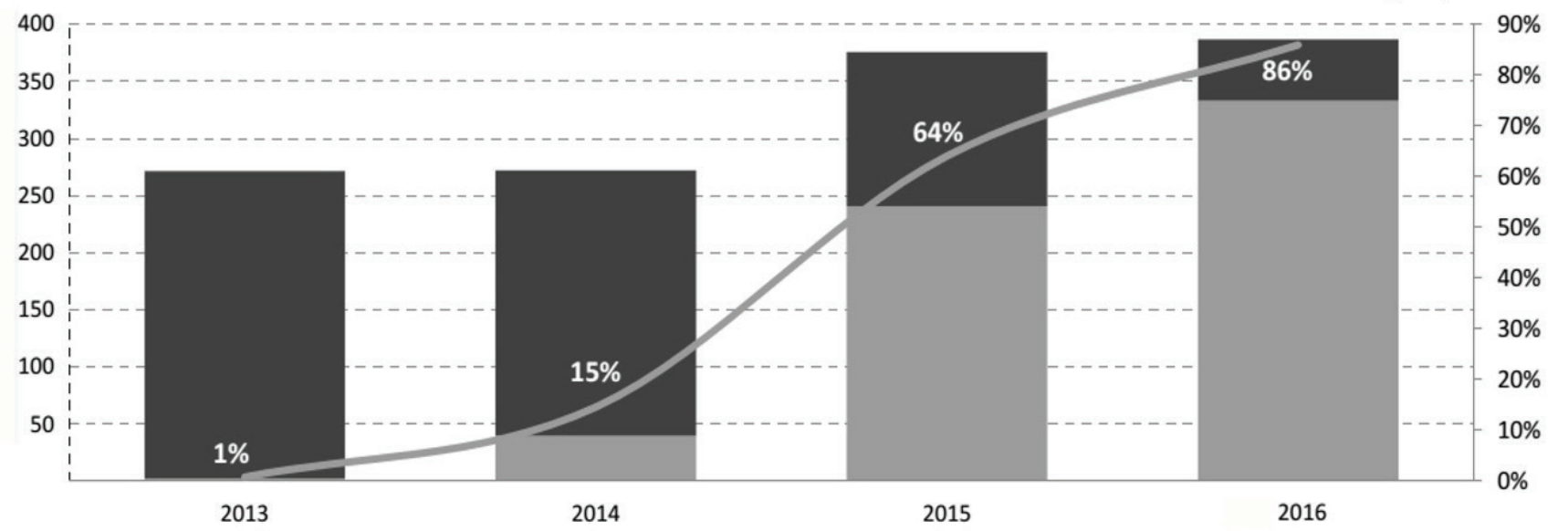

БМ, придбана на біржі,
тис. т н.е.

\section{Рис. 1. Динаміка росту обсягів біомаси, придбаної на біопаливній біржі [1].}

На біржі виконується автоматичне коригування та ранжування вартості біомаси, отриманої від різних постачальників, в залежності від відстані іiі транспортування. Це забезпечується використанням інтегрованої GPS-системи. Також у 2016 році запроваджено новий онлайн інструмент для планування графіку постачання біомаси, що підвищило ефективність функціонування біржі.

На біопаливній біржі Литви застосовується система управління ризиками та відстежується відповідність якості поставленої біомаси прийнятим технічним умовам. Це мінімізує частку біомаси неналежної якості та відсоток контрактів, що оспорюються.

По заявкам на купівлю/продаж біопалива та по укладеним контрактам учасники біржі мають надати оператору біржі засоби забезпечення виконання своїх зобов'язань. Такими засобами можуть бути кошти, що переводяться на депозитний банківський рахунок оператора або банківська гарантія першої вимоги, яка повинна бути дійсною протягом двох місяців після закінчення зазначеного в дорученні учасника або в укладеній угоді терміну доставки конкретного виду біопалива. Невикористані кошти забезпечення повертаються учас- нику після подачі оператору біржі прохання про повернення коштів через Електронну систему торгів.

Оператор біржі Baltpool регулярно проводить фінансову та технічну перевірку постійних учасників біржі, за результатами якої вони розподіляються на категорії ризику. Для кожної категорії існують свої вимоги щодо засобів забезпечення виконання зобов'язань. Для учасників біржі із категорії високого ризику застосовуються певні обмеження по обсягу та тривалості угод, що укладаються. У разі, якщо покупці або продавці не виконують взяті на себе зобов'язання, у встановлених регламентом випадках призначаються штрафи. Крім того, на користь постраждалої сторони можуть бути використані кошти забезпечення, надані оператору.

Переваги запровадження біопаливної біржі для різних гравців сектору біоенергетики та ринку в цілому можна підсумувати наступним чином. Для продавців: легкий доступ до ринку, чітко визначені правила, що $\epsilon$ однаковими для всіх. Для покупців найбільш ефективний підхід до встановлення ціни на біомасу, коротка та легка процедура покупки біомаси, систематичний контроль фінансової та технічної спроможності контрагентів. Для ринку біопалива: залучення додатко- 
вих учасників процесу купівлі/продажу, стимулювання ринкової конкуренції, стандартизація відповідних процесів та продуктів, посилення прозорості ринку та сталості сектору біоенергетики, гнучкість до нових потреб ринку, зменшення адміністративних витрат завдяки електронній системі торгів.

Наразі у керівництва Baltpool існують плани по розповсюдженню діяльності біржі на інші країни Свропи. Це буде відбуватися як шляхом створення аналогічних бірж в інших країнах, так і шляхом залучення європейських постачальників біопалива до Baltpool. На сьогодні вже $\epsilon$ успішний досвід співпраці з латвійськими компаніями, що продають біомасу на литовській біржі.

\section{Пропозиції по моделі запровадження конкурентного ринку біопалив в Украӥні}

Для запровадження та розвитку конкурентного ринку паливної біомаси в Україні вважаємо за необхідне створити біржу біопалива. Пропонуємо взяти за основу організаційну структуру литовської біопаливної біржі Baltpool 3 певними змінами, що витікають із місцевих особливостей України.

Основні характеристики запропонованої біржі біопалива в Україні:

- На біржі виконуються операції купівлі/продажу деревного палива (гранули, брикети, тріска, дрова) та біомаси аграрного походження (тюкована солома, стебла кукурудзи та соняшника, гранули, брикети).

- Всі види біопалива на біржі повинні відповідати мінімальним стандартам якості, які мають бути розроблені та доведені до відома учасників біржі.

- Розрахунок за поставлене біопаливо виконується не за об'єм або масу, а за МВт·год, тобто в залежності від його теплотворної здатності.

- Біржа біопалива функціонує у всіх областях України через її філіали, у кожній області передбачається створення одного філіалу. Спочатку планується започаткування роботи «пілотної» біржі в одній з областей на 6 місяців, потім з урахуванням результатів їі роботи буде створено філіали біопаливної біржі у всіх областях України.

- В торгах мають право брати участь державні та приватні компанії, в тому числі іноземні. Пріоритетність доступу компаній до торгів: 1) підприємства 3 області, де відбуваються торги, 2) підприємства 3 інших областей України, 3) іноземні компанії.

Біопаливна біржа може бути створена одним 3 наступних шляхів:

- заснування нової електронної торгівельної платформи;

- вдосконалення існуючої системи аукціонів 3 продажу необробленої деревини шляхом включення біопалив до переліку продукції, що реалізується, а також допущення до торгів суб'єктів господарювання, що займаються виробництвом теплової та/або електричної енергії з біомаси;

- організація нової системи аукціонів;

- використання електронного торгівельного майданчика ProZorro.

Питання вибору найбільш оптимальної моделі запровадження біопаливної біржі вимагає додаткових досліджень, а також консультацій і обговорень і3 профільними експертами та зацікавленими сторонами

Табл. 1. Технічна специфікація деревної тріски на біопаливній біржі Baltpool [5]

\begin{tabular}{|l|c|c|c|c|}
\hline \multicolumn{1}{|c|}{ Показники } & \multicolumn{3}{c|}{ Код продукту } \\
\cline { 2 - 5 } & SM1 & SM1W & SM2 & SM3 \\
\hline Вологість на робочу масу, \% & $20 \ldots 45$ & $35 \ldots 55$ & $35 \ldots 55$ & $35 \ldots 60$ \\
\hline Зольність на суху масу, \% & $\leq 2$ & $\leq 2$ & $\leq 3$ & $\leq 5$ \\
\hline $\begin{array}{l}\text { Допустимий вміст дрібної фракції } \\
(<3,15 \text { мм), \% }\end{array}$ & $<2$ & $<5$ & $<10$ & $<25$ \\
\hline $\begin{array}{l}\text { Мінімальний вміст основної фракції } \\
(3,15 . . .63 \text { мм), \% }\end{array}$ & 80 & 80 & 70 & 60 \\
\hline $\begin{array}{l}\text { Допустимий вміст крупної фракції } \\
\text { \% 100 мм, максимальний переріз 6 см })^{2},\end{array}$ & $<10$ & $<10$ & $<10$ & $<10$ \\
\hline Максимально допустима довжина фракції, мм & $<150$ & $<150$ & $<150$ & $<220$ \\
\hline Вміст хлору, \% на суху масу & $<0,02$ & $<0,02$ & $<0,02$ & $<0,03$ \\
\hline Допустимі види сировини* & 1 & $1 ; 2.1 ; 2.2$ & $1 ; 2 ; 3 ; 4.1$ & Всі види (1-4) \\
\hline Допустимі домішки сировини & - & - & $\begin{array}{c}\text { Сухе листя, } \\
\text { сухі голки }\end{array}$ & $\begin{array}{c}\text { Листя, голки } \\
\text { (у т.ч. сухі) }\end{array}$ \\
\hline
\end{tabular}

* 1 - стовбурова деревина, 2 - відходи лісопильні, 2.1 - обапіл, 2.2 - обрізки, 3 - цільні (необрізані) дерева, 4 - відходи рубок, 4.1 - надземна частина пня. 
Табл. 2. Технічна специфікація деревних гранул на біопаливній біржі Baltpool [5]

\begin{tabular}{|l|c|c|c|}
\hline \multicolumn{2}{|c|}{ Показники } & \multicolumn{3}{c|}{ Код продукту } \\
\cline { 2 - 4 } & MG1 & MG2 & MG3 \\
\hline Поперечний переріз, мм & $6 \pm 1$ або $8 \pm 1$ & $6 \pm 1$ або $8 \pm 1$ & $6 \pm 1$ або $8 \pm 1$ \\
\hline Довжина*, мм & $3,15 \ldots 40$ & $3,15 \ldots 40$ & $3,15 \ldots 40$ \\
\hline Вологість, \% на робочу масу & $\leq 10$ & $\leq 10$ & $\leq 10$ \\
\hline Зольність, \% на суху масу & $\leq 0,7$ & $\leq 1,2$ & $\leq 2,0$ \\
\hline $\begin{array}{l}\text { Стійкість до механічного руйнування, } \\
\text { \% непошкоджених гранул на робочу масу }\end{array}$ & $\geq 98,0$ & $\geq 97,5$ & $\geq 97,5$ \\
\hline Вміст дрібної фракції (<3,15 мм), \% на робочу масу & $<1,0$ & $<1,0$ & $<1,0$ \\
\hline Вміст азоту, \% на суху масу & $\leq 0,3$ & $\leq 0,5$ & $\leq 1,0$ \\
\hline Вміст сірки, \% на суху масу & $\leq 0,04$ & $\leq 0,05$ & $\leq 0,05$ \\
\hline Вміст хлору, \% на суху масу & $\leq 0,02$ & $\leq 0,02$ & $\leq 0,03$ \\
\hline Температура плавлення золи, ${ }^{\circ}$ С & $\geq 1200$ & $\geq 1100$ & $\geq 1100$ \\
\hline $\begin{array}{l}\text { Затверджений Свропейською пелетною радою } \\
\text { стандарт, що встановлює аналогічні межі якісних показників }\end{array}$ & ENplus A1 & ENplus A2 & ENplus В \\
\hline
\end{tabular}

* До 1 \% гранул можуть мати довжину 40...45 мм

Табл. 3. Технічна специфікація торфу на біопаливній біржі Baltpool [5]

\begin{tabular}{|l|c|}
\hline \multicolumn{1}{|c|}{ Показники } & Код продукту \\
\cline { 2 - 2 } & KD (нерозфасований фрезерний торф) \\
\hline Розмір фракції, мм & $0 \ldots 63$ \\
\hline Вологість, \% на робочу масу & $\leq 50$ \\
\hline Зольність, \% на робочу масу & $\leq 8$ \\
\hline Вміст хлору, \% на робочу масу & $\leq 0,03$ \\
\hline Вміст сірки, \% на робочу масу & $\leq 0,3$ \\
\hline
\end{tabular}

\section{. Висновки}

Розвиненість ринку біопалив суттєво впливає на загальні темпи розвитку сектору біоенергетики в Україні і можливість виконання цілей Національного плану дій 3 відновлюваної енергетики на період до 2020 року, а саме - досягнення $11 \%$ ВДЕ у валовому кінцевому споживанні енергії у 2020 році. Для запровадження та розвитку конкурентного ринку паливної біомаси в Україні вважаємо за необхідне створити біржу біопалива. Пропонуємо взяти за основу організаційну структуру литовської біопаливної біржі Baltpool з певними змінами, що враховують місцеві особливості в Україні.

\section{ЛІТЕРАТУРА}

1. Andrius Smaliukas. Biomass Exchange contribution to the market development: Lithuanian experience. Presentation at the 12th Int. Conf. on Biomass for Energy, 20-21 September, Kyiv, Ukraine

2. Vidmantas Macevicius. Lithuanian district heating sector: present situation and future of the Lithuanian energy market. Presentation as of 29.09.2015.

http://www.lsta.lt/files/events/2015-09-29_Danijos\%20 a mbasados $\% 20$ renginys $/ 01$ Energetikos \% 20 ministerija,\%20V.\%20Macevicius.p $\overline{\mathrm{df}}$

3. Laura Zalaite. An invitation to create unified, competitive and efficient biomass market. Presentation as of 19.04.2016.

http://docplayer.net/27383834-An-invitation-to-createunified-competitive-and-efficient-biomass-market-laurazalaite-baltpool-ceo-and-member-of-the-board-19-th-of-april-2016.html

4. Baltpool Energy Exchange Documents http://www. baltpool.1t/en/energy-exchange-documents/

5. Baltpool Energy Exchange Products http://www. baltpool.lt/en/products/

6. Baltpool Energy Exchange Trading https://e. baltpool.lt/?lang=en 


\section{CREATION OF THE COMPETITIVE BIOFUEL MARKET IN UKRAINE. PART 2}

\section{Geletukha G.G., Zheliezna T.A., Bashtovyi A.I.}

Institute of Engineering Thermophysics of the National Academy of Sciences of Ukraine, vul. Zhelyabova, 2a, Kyiv, 03680, Ukraine

Description, analysis and main results of operation of Lithuanian biomass exchange are presented. Positive impact of the biomass exchange on the development of the biofuel market in Lithuania is shown. The Biomass Exchange increased the market transparency and efficiency in Lithuania, the price difference between neighboring municipalities almost disappeared. Possible ways and models for the creation of the competitive biofuel market in Ukraine are suggested. To create and develop the competitive biofuel market in Ukraine we consider it necessary to establish the biofuel exchange. We propose to take the organizational structure of Lithuanian biomass exchange Baltpool as a basis with some changes that will take into account the local peculiarities. The proposed biofuel exchange will deal with the trading of wood fuel (pellets, briquettes, wood chips, and fuelwood) and biomass of agricultural origin (baled straw, maize and sunflower stalks, pellets, and briquettes). All types of the traded biofuel should meet the minimal quality standards, which must be developed and notified to the exchange participants. The supplied biofuel is supposed to be paid by MWh that is depending on its heating value (no payment by volume or mass). The biofuel exchange can be created by one of the following ways: establishing a new electronic trade platform; improving the existing auctions for the sale of unprocessed wood by including biofuels in the list of traded products and allowing producers of heat and/or power from biomass to participate in the trading; creating a new auction system; using the electronic trade platform ProZorro.

References 6, tables 3, figure 1 .

Key words: biomass, biofuel, wood biofuel, biofuel market, biomass exchange.

1. Andrius Smaliukas. Biomass Exchange contribution to the market development: Lithuanian experience. Presentation at the 12th Int. Conf. on Biomass for Energy, 20-21 September, Kyiv, Ukraine

2. Vidmantas Macevicius. Lithuanian district heating sector: present situation and future of the Lithuanian energy market. Presentation as of 29.09.2015.

http://www.lsta.lt/files/events/2015-09-29_Danijos\%20 a mbasados \% 20 renginys $/ 01$ Energetikos \% 20 ministerija,\%20V.\%20Macevicius.pdf

3. Laura Zalaite. An invitation to create unified, competitive and efficient biomass market. Presentation as of 19.04.2016.

http://docplayer.net/27383834-An-invitation-to-createunified-competitive-and-efficient-biomass-market-laurazalaite-baltpool-ceo-and-member-of-the-board-19-th-of-april-2016.html

4. Baltpool Energy Exchange Documents http://www. baltpool.1t/en/energy-exchange-documents/

5. Baltpool Energy Exchange Products http://www. baltpool.lt/en/products/

6. Baltpool Energy Exchange Trading https://e. baltpool.1t/?lang=en 